\title{
De rol van dementie als doodsoorzaak: overschatting bij automatisch coderen
}

\author{
Peter Harteloh · Wessel Boukema
}

Published online: 11 February 2019

(C) The Author(s) 2019

\begin{abstract}
Samenvatting Wij onderzochten de validiteit van de codering van dementie als onderliggende doodsoorzaak bij automatisch coderen (IRIS). Met behulp van een vragenlijst werden 690 artsen gevraagd naar hun mening over de causale rol van dementie bij overlijden. Voor het versturen van de vragenlijst werd een steekproef getrokken uit doodsoorzakenformulieren waarop in 2017 een niet nader gespecificeerde vorm van dementie (ICD-10 code: F03) was vermeld. De artsen beantwoordden de vragenlijst aan de hand van het door henzelf ingevulde doodsoorzakenformulier. We vergeleken vervolgens de mening van de arts met de uitkomst van het automatisch coderen voor het desbetreffende sterfgeval. De vragenlijst werd door 448 artsen $(65 \%)$ ingevuld. Gelet op het oordeel van de arts bleek de frequentie van dementie als onderliggende doodsoorzaak bij automatisch coderen met $9 \%$-punt (95\%-BI: $5 \%-14 \%$ ) te worden overschat. Dit komt neer op een relatieve overschatting van bijna $23 \%$ in de doodsoorzakenstatistiek. De betekenis van dit gegeven is tweeërlei. Bij internationale vergelijking van dementie als doodsoorzaak kan de uitkomst van automatisch coderen worden gebruikt, maar bij de interpretatie van nationale ontwikkelingen dient het oordeel van de arts te worden meegewogen om de betekenis van het ziektebeeld bij overlijden duidelijk te krijgen.
\end{abstract}

Trefwoorden doodsoorzakenstatistiek · dementie • onderliggende doodsoorzaak · doodsoorzakenformulier $\cdot$ automatisch coderen $\cdot$ IRIS

Dr. P. Harteloh $(\varangle) \cdot$ W. Boukema

Afdeling Gezondheid en Zorg, CBS, Den Haag, Nederland ppm.harteloh@cbs.nl

\section{The role of dementia as cause of death}

Abstract We evaluated the increase of dementia as underlying cause of death (18\%) when we started to use an automated coding system (IRIS) for cause-ofdeath statistics. A questionnaire was sent to a random sample of certifiers ( $n=690)$ who mentioned 'dementia' (ICD-10 code: F03) on a death certificate in 2017. The certifiers were asked questions about the causal role of dementia on the certificate filled in. We compared the opinion of the certifier with the outcome of automated coding. A response of $65 \%$ $(n=448)$ was obtained. With regard to the opinion of the certifier, the frequency of dementia as underlying cause of death was overestimated 9\%-point (95\%CI: $5 \%-14 \%$ ) by the automated coding system, corresponding to a relative overestimation of almost $23 \%$ in cause-of-death statistics. Users of cause-of-death statistics should be aware of this. For international comparison of data on dementia as a cause of death the outcome of automated coding can be used. However, for interpreting national developments the intention of the certifier should be taken into account.

Keywords Cause-of-death statistics · Dementia - Underlying cause of death - Death certificate $\cdot$ Automated coding $\cdot$ IRIS

\section{Inleiding}

In 2013 is het Centraal Bureau voor de Statistiek (CBS) overgegaan op het automatisch coderen van doodsoorzaken [1]. Dit bracht opmerkelijke veranderingen in het voorkomen van een aantal belangrijke doodsoorzaken met zich mee. Zo nam het percentage gevallen met niet nader gespecificeerde dementie (ICD-10 code: F03) als onderliggende doodsoorzaak tussen 2012 (handmatig gecodeerd) en 2013 (automa- 


\section{Kernpunten}

- Bij de invoering van automatisch coderen steeg de frequentie van dementie in de doodsoorzakenstatistiek van het Centraal Bureau voor de Statistiek (CBS) met ruim $18 \%$. Dit riep de vraag op naar de validiteit van de data.

- Uit ons onderzoek blijkt dat de frequentie van dementie als onderliggende doodsoorzaak bij automatisch coderen met ongeveer $23 \%$ wordt overschat.

- Hieraan liggen slecht ingevulde doodsoorzakenformulieren, begripsverwarring, tekortkomingen van de software en hiaten in causaal redeneren ten grondslag.

- Nuancering van gebruikte CBS-cijfers over dementie is aangewezen.

- Bij internationale vergelijkingen van dementie als doodsoorzaak kan het resultaat van automatisch coderen worden gebruikt. Bij nationaal gebruik voor trends of (rang)ordeningen dient de opvatting van de arts te worden meegewogen.

tisch gecodeerd) met maar liefst $18 \%$ toe [2]. Deze plotselinge toename riep vragen op bij gebruikers van de doodsoorzakenstatistiek en was voor het CBS aanleiding om een onderzoek naar de validiteit van de uitkomst van automatisch coderen te verrichten. Voor de statistiek wordt de onderliggende doodsoorzaak geselecteerd uit de op een doodsoorzakenformulier genoteerde ziektebeelden [3]. Sinds 2013 wordt dit gedaan door IRIS: een in internationaal verband ontwikkeld softwarepakket voor het automatisch coderen van doodsoorzaken [4]. De input van IRIS wordt gevormd door het doodsoorzakenformulier (fig. 1) waarop een (schouwend) arts de met het overlijden samenhangende ziekten of aandoeningen in causale samenhang noteert [5]. De validiteit van automatisch coderen berust op een correcte interpretatie van een correct ingevuld doodsoorzakenformulier. Om een beeld te krijgen van de validiteit onderzochten wij de opvattingen van artsen over de causale rol die dementie bij overlijden speelt en de manier waarop zij deze op het doodsoorzakenformulier noteren in relatie tot de uitkomsten van automatisch coderen. De resultaten van ons onderzoek nopen tot een nuancering van de cijfers over de sterfte aan dementie.

\section{Methode}

Om de rol van dementie als doodsoorzaak te onderzoeken is er een vragenlijst opgesteld. De vragen komen voort uit literatuuronderzoek en zijn getest door deze voor te leggen aan een aantal inhoudsdeskundigen. De vragenlijst bestond uit 23 meerkeuzevragen die betrekking hadden op: a) kenmerken van de respondent (4 vragen), b) de manier waarop de diagnose dementie is gesteld ( 9 vragen) en c) de causale rol

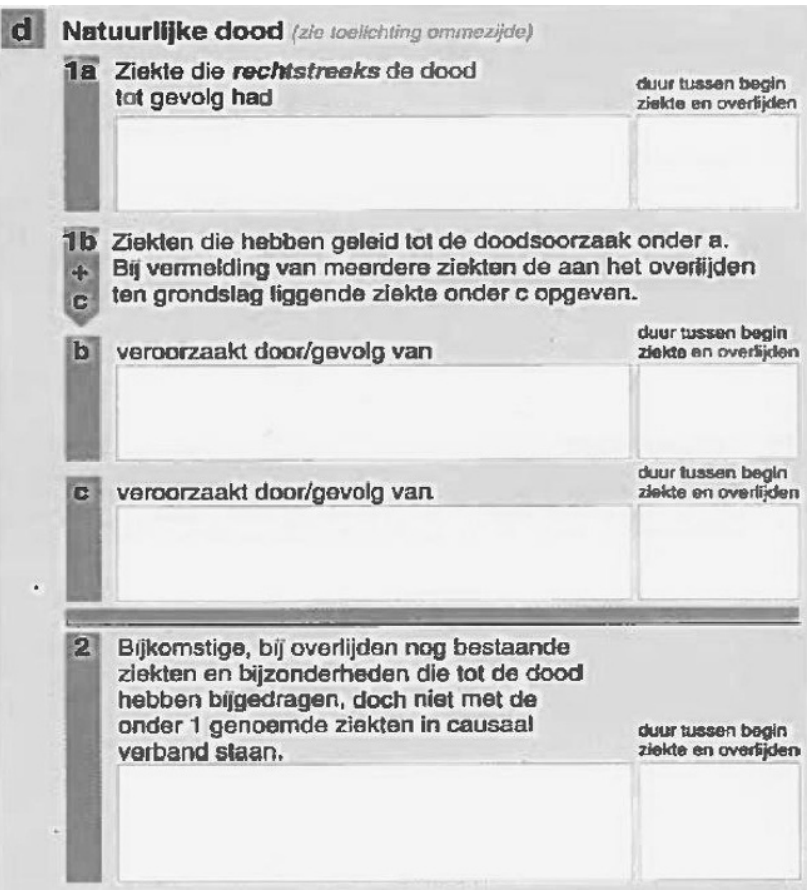

Figuur 1 Het gedeelte van het doodsoorzakenformulier waarop de causale samenhang van ziekten bij overlijden wordt genoteerd. Op het onderste (beschreven) vakje (deel $1 \mathrm{~b}$ of deel 1c) staat de onderliggende doodsoorzaak (bijvoorbeeld: dementie). Deel $1 \mathrm{a}$ is bestemd voor de directe doodsoorzaak (bijvoorbeeld: cachexie, dehydratie). Op deel 1b kan een intermediërende doodsoorzaak worden vermeld (bijvoorbeeld: stop eten/drinken of slikstoornis). De onderliggende doodsoorzaak schuift dan door naar deel 1c. Deel 2 bevat de bijdragende doodsoorzaak, dat wil zeggen, de ziekte zonder welke de patiënt niet aan de op deel 1 vermelde onderliggende doodsoorzaak zou zijn overleden (bijvoorbeeld: nierfalen)

van dementie bij overlijden (10 vragen), en werd afgesloten met de open vraag of de respondent na het invullen van de vragenlijst het oorspronkelijk ingestuurde doodsoorzakenformulier anders zou hebben ingevuld.

In dit artikel doen we verslag van onderdeel c: de causale rol van dementie bij overlijden. Ten eerste bevatte dit onderdeel een vraag om vast te stellen of dementie (überhaupt) een causale rol bij overlijden heeft gespeeld, namelijk of 'de patiënt ook zou zijn overleden als deze ten tijde van het overlijden niet aan dementie zou hebben geleden' (de zogenaamde counterfactual) [6, 7]. Stel dat een patiënt met dementie een longontsteking krijgt en overlijdt. Als de patiënt ook aan de longontsteking zou zijn overleden als deze geen dementie zou hebben gehad (bijvoorbeeld door besmetting met een moeilijk te behandelen/resistente bacterie), speelde de dementie feitelijk geen causale rol bij het overlijden en wordt de vraag met 'ja' beantwoord. Een negatief antwoord kenmerkt dementie echter als een voldoende of zelfs noodzakelijke voorwaarde voor overlijden. Ook werd er rechtstreeks gevraagd of dementie losstond van het overlijden. Vervolgens werd de rol van dementie als doods- 
Tabel 1 Respons naar specialisme van de aangeschreven artsen $(n=690)$

\begin{tabular}{|c|c|c|}
\hline & aantal & $\%$ \\
\hline vragenlijst ingevuld retour (respons) & 448 & 65 \\
\hline geen enkele reactie (non-respons) & 178 & 26 \\
\hline vragenlijst retour, maar niet ingevuld door baanwisselingen of locatiewijzigingen (of soortgelijke reactie) & 64 & 9 \\
\hline \multicolumn{3}{|l|}{ specialisme van respondenten $(n=448)$} \\
\hline huisartsgeneeskunde & 81 & 18 \\
\hline ouderengeneeskunde & 298 & 67 \\
\hline ouderengeneeskunde (niet) in opleiding & 37 & 8 \\
\hline geriatrie & 2 & 1 \\
\hline neurologie & 1 & 0 \\
\hline anders & 29 & 6 \\
\hline
\end{tabular}

oorzaak verder onderzocht door vragen te stellen over de ernst, de duur, het belang en de aard van de doodsoorzaak (direct, onderliggend, bijdragend). De vragen betroffen het door de arts zelf ingevulde (oorspronkelijke) doodsoorzakenformulier. Een kopie ervan werd met de vragenlijst meegestuurd. Op deze manier werd de betekenis van het (feitelijk) ingevulde doodsoorzakenformulier onderzocht.

De vragenlijst is aan 690 artsen gestuurd, op basis van een aselecte steekproef van doodsoorzakenformulieren waarop niet nader gespecificeerde dementie (ICD-10 code: F03) werd vermeld, ongeacht of dit ziektebeeld bij automatisch coderen al dan niet als onderliggende doodsoorzaak is geselecteerd. Het steekproefkader werd gevormd door 9.889 doodsoorzakenformulieren ingevuld in 2017, zes maanden voor het moment van verzending van de vragenlijst, om geheugeneffecten zo veel mogelijk te voorkomen. Bij een correct ingevuld doodsoorzakenformulier geeft de positie van dementie op het formulier de rol van het ziektebeeld bij overlijden weer (zie fig. 1). De steekproef werd daarom gestratificeerd getrokken met evenveel vermeldingen van dementie op deel 1 vakje $1 \mathrm{a}, 1 \mathrm{~b} / \mathrm{c}$ of deel $2(n=230$ per positie), in het streven naar een respons van minimaal 100 per positie. Voor het vertalen van de uitkomst van ons onderzoek naar de doodsoorzakenstatistiek werden de resultaten gewogen naar positie op het doodsoorzakenformulier. Het gewicht werd berekend door de (procentuele) vermelding van dementie op een bepaalde positie in de populatie van alle doodsoorzakenformulieren van de statistiekjaren 2013-2016 te delen door de (procentuele) vermelding van dementie op dezelfde positie van het doodsoorzakenformulier in de respons. De steekproef werd beperkt tot natuurlijke doden (dat wil zeggen tot een overlijden door ziekte, niet door een ongeval, suïcide of geweld). Na een maand is een herinnering verstuurd aan artsen die de vragenlijst nog niet hadden teruggestuurd.

De analyse van het materiaal is uitgevoerd met behulp van het softwarepakket $\mathrm{R}$, versie 3.2.7 (januari 2018). Met behulp van een meervoudige logistische regressieanalyse is onderzocht welke factoren de selectie van dementie als onderliggende doodsoorzaak bepalen. Het oordeel van de arts en de uitkomst van het automatisch coderen fungeerden respectievelijk in twee verschillende regressiemodellen als afhankelijke variabelen, gedichotomiseerd op de selectie van dementie als onderliggende doodsoorzaak (ja/nee). De vragen over causaliteit (deel c van de vragenlijst) fungeerden als onafhankelijke variabelen. Deze werden stapsgewijs aan het model toegevoegd en alleen behouden bij een $p$-waarde van minder dan $5 \%$. Het model is uitsluitend gebaseerd op het aantal respondenten dat alle vragen over causaliteit heeft beantwoord $(n=241)$. Hierdoor is het model op een subpopulatie van de respons gebaseerd. Het logistische regressiemodel heeft een oddsratio (OR) als uitkomstmaat. Deze wordt zowel univariaat als gecorrigeerd voor alle andere variabelen gepresenteerd.

\section{Materiaal}

Van de aangeschreven artsen stuurde $65 \%$ een ingevulde vragenlijst terug $(n=448)$. Bijna $9 \%$ van de aangeschreven artsen gaf om administratieve redenen aan de vragenlijst niet meer te kunnen invullen. $\mathrm{Zij}$ waren van baan veranderd en/of het dossier van de overleden patiënt was voor hen niet meer bereikbaar of onvoldoende vers in het geheugen. De eigenlijke non-respons bedroeg daarmee $26 \%$ (tab. 1).

Het aantal specialisten ouderengeneeskunde domineert de respons (tab. 1). Dit komt doordat veel mensen met een vermelding van dementie op het doodsoorzakenformulier in het verpleeghuis overlijden (tab. 2). De nagenoeg identieke verdeling naar plaats van overlijden wijst op een representatief karakter van de respons ten opzichte van de steekproef en/of het steekproefkader.

\section{Resultaten}

Wanneer een arts dementie op een doodsoorzakenformulier heeft vermeld, kent deze het ziektebeeld in $41 \%$ van de gevallen de rol van onderliggende doodsoorzaak toe. In $17 \%$ van de gevallen noemt de arts dementie 'directe doodsoorzaak' en in $30 \%$ van de gevallen 'bijdragende doodsoorzaak'. In bijna $13 \%$ van 
Tabel 2 Plaats van overlijden van personen met dementie naar respons, steekproef en steekproefkader (percentages)

\begin{tabular}{|c|c|c|c|}
\hline plaats van overlijden & $\begin{array}{l}\text { respons } \\
(n=448)\end{array}$ & $\begin{array}{l}\text { steekproef } \\
(n=690)\end{array}$ & $\begin{array}{l}\text { steekproefkader } \\
(n=9.989)\end{array}$ \\
\hline thuis & 7 & 6 & 6 \\
\hline verpleeghuis & 80 & 80 & 80 \\
\hline ziekenhuis & 2 & 2 & 3 \\
\hline verzorgingshuis & 8 & 9 & 8 \\
\hline overige instellingen & 2 & 2 & 2 \\
\hline onbekend & 1 & 1 & 1 \\
\hline
\end{tabular}

Tabel 3 De rol van dementie als doodsoorzaak volgens de arts naar de plaats van vermelding op het doodsoorzakenformulier en naar de uitkomst van automatisch coderen (aantallen; $n=440^{\text {a) }}$

\begin{tabular}{|c|c|c|c|c|c|}
\hline $\begin{array}{l}\text { dementie } \\
\text { (ICD-10: F03) }\end{array}$ & directe doodsoorzaak & $\begin{array}{l}\text { onderliggende } \\
\text { doodsoorzaak }\end{array}$ & $\begin{array}{l}\text { bijdragende } \\
\text { doodsoorzaak }\end{array}$ & $\begin{array}{l}\text { losstaand van het } \\
\text { overlijden }\end{array}$ & $\begin{array}{l}\text { totaal, } \\
n(\%)\end{array}$ \\
\hline \multicolumn{6}{|l|}{ plaats op formulier } \\
\hline deel 1, vak 1a & 53 & 59 & 11 & 6 & $129(29)$ \\
\hline deel 1 , vak $1 b / 1 c$ & 21 & 94 & 34 & 3 & $152(35)$ \\
\hline deel 2 & 0 & 26 & 87 & 46 & $159(36)$ \\
\hline \multicolumn{6}{|l|}{ bij automatisch coderen } \\
\hline $\begin{array}{l}\text { onderliggende doodsoor- } \\
\text { zaak }\end{array}$ & 65 & 154 & 58 & 18 & $295(67)$ \\
\hline $\begin{array}{l}\text { geen onderliggende doods- } \\
\text { oorzaak }\end{array}$ & 9 & 25 & 74 & 37 & $145(33)$ \\
\hline totaal, $n$ (\%) & $74(17)$ & $179(41)$ & $132(30)$ & $55(13)$ & $440(100)$ \\
\hline
\end{tabular}

de gevallen geeft de arts aan dat dementie ondanks de vermelding op het doodsoorzakenformulier geen rol bij het overlijden heeft gespeeld (tab. 3).

In $85 \%(153 / 179)$ van de gevallen waarin dementie door de arts tot onderliggende doodsoorzaak wordt bestempeld, staat het ziektebeeld (terecht) op deel 1 van het doodsoorzakenformulier. In $15 \%(26 / 179)$ van deze gevallen staat dementie echter op deel 2 genoteerd (ofwel als bijdragende doodsoorzaak) en in $33 \%(59 / 179)$ wordt het ziektebeeld op het vak la (de plek voor de directe doodsoorzaak) vermeld.

In $17 \%$ van de gevallen noemt de invullend arts dementie een 'directe doodsoorzaak', terwijl uit de locatie op het formulier blijkt dat onderliggende doodsoorzaak wordt bedoeld. Dementie is geen verschijnsel van overlijden, zoals een hartstilstand of ademhalingsdepressie, en hoort daarom niet op vak la te staan. Vermelding van dementie op deze positie moet daarom, mede gelet op het aantal gevallen (59) waarin de arts dementie op vak la onderliggende doodsoorzaak noemt, worden gelezen als het weglaten van de directe doodsoorzaak bij het invullen van het doodsoorzakenformulier. Bij een vermelding op $1 \mathrm{~b}$ heeft dementie altijd iets anders (op la) veroorzaakt en is de term 'directe doodsoorzaak' ook niet van toepassing.

In $66 \%(87 / 132)$ van de gevallen waarin de invullend arts dementie een bijdragende doodsoorzaak noemt, staat dementie terecht op deel 2 van het doodsoorzakenformulier genoteerd. Een vermelding op deel 1 van het doodsoorzakenformulier sluit een rol als bijdragende doodsoorzaak niet uit (bijvoorbeeld door ziektebeelden naast elkaar in één vakje te noteren), maar is gelet op de werkwijze bij automatisch coderen niet wenselijk. Het veroorzaakt ambiguïteit - er moet een keuze worden gemaakt die de software op het verkeerde been kan zetten.

De aanduiding 'losstaand van het overlijden' duidt op een invulfout. Dementie had niet op het doodsoorzakenformulier vermeld hoeven te worden. Veelal (83\% van de gevallen) staat dementie dan op deel 2. In $33 \%(18 / 55)$ van deze gevallen wordt dementie bij automatisch coderen echter (ten onrechte) als onderliggende doodsoorzaak geselecteerd.

Uit ons onderzoek blijkt dementie in $29 \%(126 / 440)$ van de gevallen niet op de positie van het doodsoorzakenformulier te staan die overeenkomt met de bedoeling van de arts (zie ook fig. 1). In 26 gevallen noemt de arts dementie 'onderliggende doodsoorzaak', maar wordt het ziektebeeld als bijkomende doodsoorzaak op deel 2 van het doodsoorzakenformulier genoteerd. Er zijn $45(11+34)$ gevallen waarbij de arts dementie als bijkomende doodsoorzaak op deel 1 in plaats van op deel 2 noteert en 55 maal hoorde dementie eigenlijk helemaal niet op het doodsoorzakenformulier vermeld te worden, omdat het losstond van het overlijden. 
Tabel 4 Overschatting van dementie als onderliggende doodsoorzaak (ODO) bij automatisch coderen (AC) (aantallen en percentages)

\begin{tabular}{|c|c|c|c|c|c|c|c|c|}
\hline \multirow[b]{2}{*}{$\begin{array}{l}\text { positie de- } \\
\text { mentie op } \\
\text { DOF }\end{array}$} & \multicolumn{3}{|c|}{ respons van steekproef } & \multirow{2}{*}{$\begin{array}{l}\text { percentage } \\
\text { vermelding de- } \\
\text { mentie op DOF } \\
\text { naar positie } \\
\text { respons } \\
\text { van steekproef }\end{array}$} & \multirow[b]{2}{*}{$\begin{array}{l}\text { bestand } \\
\text { 2013-2016 }\end{array}$} & \multirow[t]{2}{*}{ gewicht } & \multicolumn{2}{|c|}{ doodsoorzakenstatistiek } \\
\hline & ODO AC & ODO Arts & verschil & & & & ODO AC & verschil \\
\hline vak 1a & 106 & 112 & -6 & 29 & 11 & 0,38 & 40 & -2 \\
\hline vak $1 \mathrm{~b} / \mathrm{c}$ & 135 & 115 & 20 & 35 & 38 & 1,09 & 147 & 22 \\
\hline deel 2 & 54 & 26 & 28 & 36 & 51 & 1,42 & 77 & 40 \\
\hline totaal & 295 & 253 & 42 & 100 & 100 & & 266 & 60 \\
\hline$\%$ : verschil & & & 14,2 & & & & & 22,6 \\
\hline $95 \%-B \mid$ & & \multicolumn{2}{|l|}{$10,3-18,2$} & & & & \multicolumn{2}{|l|}{$17,5-27,6$} \\
\hline
\end{tabular}

In $25 \%$ van de gevallen (110/440) stemt de uitkomst van het automatisch coderen niet overeen met de rol die de arts het ziektebeeld bij overlijden toeschrijft. Van de gevallen waarbij de arts dementie als onderliggende doodsoorzaak beschouwt, worden er $34(9+25)$ niet als zodanig gecodeerd, en $76(58+18)$ gevallen waarbij de arts dementie niet als onderliggende doodsoorzaak beschouwt, worden wel zo gecodeerd. Deze laatste vormen $26 \%$ van de 295 gevallen die bij automatisch coderen als onderliggende doodsoorzaak worden aangewezen.

Bij automatisch coderen wordt dementie in $67 \%$ van de gevallen als onderliggende doodsoorzaak aangewezen - de arts doet dit slechts in $41 \%$ van deze (zelfde) gevallen. Tellen we de gevallen waarin de arts spreekt over 'directe doodsoorzaak', maar onderliggende doodsoorzaak blijkt te bedoelen bij de als zodanig benoemde gevallen op $(41+17=58 \%)$, dan blijft er een statistisch significant (z-toets) verschil van $9 \%$-punt (95\%-BI 5-14\%) met de uitkomst van het automatisch coderen over. De relatieve overschatting van dementie als onderliggende doodsoorzaak bij automatisch coderen bedraagt in ons onderzoek $14,2 \%$ (95\%-BI 10,3-18,2\%). Gewogen naar de positie van dementie op het doodsoorzakenformulier betekent dit een overschatting van dementie als onderliggende doodsoorzaak met $22,6 \%$ in de doodsoorzakenstatistiek (95\%-BI 17,5-27,6\%; tab. 4).

Wanneer we de vragen over causaliteit samenbrengen in een multivariaat logistisch regressiemodel bepaalt alleen de positie van dementie op het doodsoorzakenformulier de rol van dementie als onderliggende doodsoorzaak bij automatisch coderen. Het oordeel van de arts over de rol van dementie als onderliggende doodsoorzaak wordt bepaald door de ernst van het ziektebeeld bij overlijden, de mate waarin dementie de symptomen veroorzaakt waar de patiënt aan overlijdt, de positie van vermelding op het doodsoorzakenformulier en de counterfactual (tab. 5). Het antwoord op de vraag naar de counterfactual bleek hoog gecorreleerd met het antwoord op de vraag naar het belang van dementie bij het overlijden. Deze vragen waren uitwisselbaar in het model. Het geeft aan dat de counterfactual mag worden opgevat als de (logische) uitdrukking van het belang van dementie bij overlijden. De vragen of 'het lijden aan dementie werd verergerd door andere ziekten', 'dementie andere ziekten veroorzaakte' en 'dementie bijdroeg aan de ernst van andere ziekten bij overlijden' speelden geen significante rol als determinanten in het model, hetgeen wijst op de relatief autonome rol die dementie als doodsoorzaak in de ogen van de arts speelt. De duur van het ziektebeeld, en de leeftijd en het geslacht van de patiënt speelden geen statistisch significante rol bij het selecteren van dementie als onderliggende doodsoorzaak.

De vraag of de respondent na het invullen van de vragenlijst het oorspronkelijk ingestuurde doodsoorzakenformulier anders zou hebben ingevuld, werd door 7,8 \% met 'ja' beantwoord. Het merendeel (41\%) van deze respondenten verplaatst dementie van deel 1 naar deel 2 van het doodsoorzakenformulier, dat wil zeggen, kent dementie bij nader inzien de rol van bijkomende doodsoorzaak toe. Twaalf procent van deze respondenten besluit om dementie van het doodsoorzakenformulier te schrappen en het ziektebeeld bij nader inzien geen rol meer als doodsoorzaak toe te kennen en $32 \%$ verandert de positie van dementie in deel 1, voornamelijk van directe (deel 1a) naar onderliggende doodsoorzaak (deel lb/c).

\section{Beschouwing}

Naar aanleiding van een forse stijging in de frequentie van dementie als onderliggende doodsoorzaak bij de invoering van automatisch coderen hebben wij nader onderzoek verricht naar de validiteit van de uitkomsten van deze werkwijze. Wij vergeleken het klinisch oordeel van de arts over de rol van dementie bij overlijden met de uitkomst van het automatisch coderen van een doodsoorzakenformulier. Uit ons onderzoek blijkt dat 1) dementie wordt overschat als onderliggende doodsoorzaak bij automatisch coderen, 2) verkeerd invullen van het doodsoorzakenformulier een 


\section{Wetenschappelijk artikel}

Tabel 5 Determinanten van dementie als onderliggende doodsoorzaak (ODO), $n=241$

\begin{tabular}{|c|c|c|c|c|c|c|}
\hline \multirow[b]{2}{*}{ Onafhankelijke variabele in model } & \multicolumn{3}{|c|}{$\begin{array}{l}\text { Dementie } 0 \text { DO volgens arts } \\
\text { totaal: } 63,9 \% \\
(57,8-70,0 \%)\end{array}$} & \multicolumn{3}{|c|}{$\begin{array}{l}\text { Dementie ODO bij AC } \\
\text { totaal: } 72,2 \% \\
(66,5-77,8 \%)\end{array}$} \\
\hline & $\%$ & $\begin{array}{l}\text { OR } \\
(95 \%-B I)\end{array}$ & $\begin{array}{l}\text { GOR } \\
\text { (95\%-BI) }\end{array}$ & $\%$ & $\begin{array}{l}\text { OR } \\
\text { (95\%-BI) }\end{array}$ & $\begin{array}{l}\text { GOR } \\
\text { (95\%-BI) }\end{array}$ \\
\hline \multicolumn{7}{|c|}{ Ernst dementie bij overlijden speelde grote rol? } \\
\hline nee, $n=33$ & 15,2 & 1,0 & 1,0 & 39,4 & 1,0 & 1,0 \\
\hline ja, $n=208$ & 71,6 & 14,1 & 6,6 & 77,4 & 5,3 & 1,6 \\
\hline & & $(5,2-38,4)$ & $(1,6-26,4)$ & & $(2,4-11,4)$ & $(0,6-4,1)$ \\
\hline \multicolumn{7}{|l|}{ Positie van dementie op DOF } \\
\hline Deel $2, n=79$ & 21,5 & 1,0 & 1,0 & 36,7 & 1,0 & 1,0 \\
\hline Deel $1, n=162$ & 84,6 & 20,0 & 9,6 & 89,5 & 14,7 & 8,9 \\
\hline & & $(10,1-39,7)$ & $(4,2-21,6)$ & & $(7,5-29,0)$ & $(4,2-18,9)$ \\
\hline \multicolumn{7}{|c|}{ Persoon ook overleden als deze indertijd niet aan dementie zou hebben geleden? (counterfactual) } \\
\hline ja, $n=93$ & 37,6 & 1,0 & 1,0 & 55,9 & 1,0 & 1,0 \\
\hline nee, $n=148$ & 80,4 & 6,8 & 2,3 & 82,4 & 3,7 & 1,4 \\
\hline & & $(3,8-12,2)$ & $(1,0-5,2)$ & & $(2,1-6,7)$ & $(0,6-3,1)$ \\
\hline \multicolumn{7}{|c|}{ Dementie veroorzaakte de symptomen waaraan patiënt is overleden? } \\
\hline nee, $n=91$ & 26,4 & 1,0 & 1,0 & 49,5 & 1,0 & 1,0 \\
\hline $\mathrm{ja}, n=150$ & 86,7 & 18,1 & 7,6 & 86,0 & 6,3 & 2,1 \\
\hline & & $(9,3-35,2)$ & $(3,4-17,1)$ & & $(3,4-11,6)$ & $(0,9-4,7)$ \\
\hline
\end{tabular}

oorzaak is van de overschatting van dementie als onderliggende doodsoorzaak bij automatisch coderen, 3) begripsverwarring een oorzaak is van verkeerd ingevulde doodsoorzakenformulieren, en 4) automatisch coderen (nog) niet goed is afgestemd op de klinische praktijk.

\section{Een overschatting van dementie als onderliggende doodsoorzaak bij automatisch coderen}

In $25 \%$ van de gevallen stemde de opvatting van de arts over de rol van dementie bij overlijden niet overeen met de uitkomst van het automatisch coderen. Vooralsnog is er geen gouden standaard om deze discrepantie te interpreteren. Het doodsoorzakenformulier kan echter worden beschouwd als een uitvraag van een causaal verband bij overlijden. Hierop worden internationale richtlijnen voor de selectie van een onderliggende doodsoorzaak toegepast. Het zou vreemd zijn daarbij voorbij te gaan aan het oordeel van de invuller. Hiervoor zijn inhoudelijke noch epidemiologische redenen. ${ }^{1}$ Uitgaande van het perspectief van de arts is er dan ook sprake van een overschatting van dementie als onderliggende doodsoorzaak bij automatisch coderen. De overschatting komt grotendeels doordat $26 \%$ van de gevallen die bij automatisch coderen dementie als onderliggende

\footnotetext{
${ }^{1}$ Zo schrijft de WHO bijvoorbeeld op epidemiologische gronden voor om ondanks het causaal verband tussen roken en longkanker, longkanker als onderliggende doodsoorzaak in de statistiek op te nemen [3].
}

doodsoorzaak krijgen toegewezen, berusten op gevallen waaraan de arts het ziektebeeld de rol van bijdragende doodsoorzaak toekent of zelfs ziet als losstaand van het overlijden.

\section{Verkeerd invullen van het doodsoorzakenformulier leidt bij automatisch coderen tot overschatting van dementie als onderliggende doodsoorzaak}

Invulfouten kunnen de software bij automatisch coderen op een verkeerd been zetten. Dit draagt bij aan een overschatting van dementie als onderliggende doodsoorzaak, wat niet zozeer te wijten aan de software, als wel aan de wijze waarop het doodsoorzakenformulier is ingevuld.

Ten eerste wordt dementie vaker op een doodsoorzakenformulier vermeld dan de bedoeling is. Bij het invullen van een doodsoorzakenformulier dient de (schouwend) arts in de eerste plaats vast te stellen of een ziektebeeld (überhaupt) een causale rol bij overlijden heeft gespeeld. Ziekten aanwezig bij overlijden zonder enig causaal verband met deze tragische gebeurtenis, horen niet op een doodsoorzakenformulier thuis [8]. De counterfactual is hier van belang. ${ }^{2}$ $\mathrm{Er}$ is een sterk verband met het oordeel van de arts $(\mathrm{OR}=2,3)$. Toch wordt de counterfactual niet altijd

\footnotetext{
${ }^{2}$ Het doodsoorzakenformulier is dus geen afspiegeling van het medisch dossier bij overlijden, maar bevat een gerichte selectie van ziekten of aandoeningen uit de voorgeschiedenis of actuele probleemlijst van een patiënt, die een causale rol bij overlijden speelden.
} 
(correct) toegepast. In ons onderzoek gaf $13 \%$ van de respondenten aan dat dementie eigenlijk geen rol bij het overlijden had gespeeld. Dementie had dan niet op het doodsoorzakenformulier horen te staan. De software selecteert dementie daardoor in ruim $4 \%$ $(18 / 440)$ van de gevallen als onderliggende doodsoorzaak, terwijl dat niet de bedoeling is.

Ten tweede komt de positie van dementie op het doodsoorzakenformulier niet altijd overeen met de rol die de arts het ziektebeeld bij overlijden toekent. Wanneer de arts spreekt over een 'onderliggende doodsoorzaak' staat dementie in $15 \%$ van de gevallen op deel 2 en niet op deel 1 van het doodsoorzakenformulier genoteerd, en wanneer deze dementie een bijdragende doodsoorzaak noemt staat het ziektebeeld in $34 \%$ van de gevallen op deel 1 in plaats van op deel 2 genoteerd. De positie van dementie op het doodsoorzakenformulier blijkt de enige determinant van de selectie van dementie als onderliggende doodsoorzaak bij automatisch coderen $(\mathrm{OR}=8,7)$. Een verkeerde positie kan de uitkomst van het automatisch coderen dan ook in negatieve zin beïnvloeden. Gelet op de bedoeling van de invuller bleek dat dementie in $29 \%$ van de door ons onderzochte formulieren op een verkeerde positie was vermeld. In de literatuur wordt de proportie verkeerd ingevulde doodsoorzakenformulieren, ongeacht de doodsoorzaak, geschat op 33 tot $40 \%$ [9, 10]. De rapportage van dementie als doodsoorzaak steekt hier niet ongunstig tegen af.

\section{Begripsverwarring als oorzaak van verkeerd ingevulde doodsoorzakenformulieren}

Naast een verkeerde positie van dementie op een doodsoorzakenformulier is er ook sprake van een begripsverwarring bij het invullen van het doodsoorzakenformulier [11]. In $17 \%$ van de gevallen werd dementie door de respondent als directe doodsoorzaak aangeduid, terwijl het dat niet kan zijn. ${ }^{3}$ Een directe doodsoorzaak veroorzaakt de definitieve verstoring van de homeostase, waardoor de persoon overlijdt. Voorbeelden van directe doodsoorzaken zijn hartstilstand, hartfalen, respiratoire insufficiëntie of nierfalen. Een aanduiding van dementie als directe doodsoorzaak is dan ook niet terecht. $\mathrm{Er}$ is altijd een pathologisch verschijnsel tussen dementie en de dood in gelegen, zoals stoppen met eten of drinken, een infectie van de lucht- of urinewegen of een val door evenwichtsstoornissen. In $88 \%(65 / 74)$ van de gevallen waarin de respondenten (ten onrechte) dementie een directe doodsoorzaak noemen, selecteert de software het ziektebeeld dan wel als onderliggende

\footnotetext{
3 Het CBS krijgt geregeld de opmerking dat 'dementie toch geen doodsoorzaak kan zijn'. Deze critici denken dan aan een directe doodsoorzaak en kunnen zich (terecht) niet voorstellen dat dementie als zodanig functioneert. Het CBS rapporteert echter onderliggende doodsoorzaken volgens WHO/ICD-10 conventies.
}

doodsoorzaak, waardoor deze begripsverwarring geen grote statistische gevolgen heeft. De verschillende soort doodsoorzaken worden echter door de arts in de praktijk niet altijd op dezelfde manier gedefinieerd als de WHO dat in deel 2 van de ICD-10 doet [3]. Een begripsverheldering bij de invulinstructies van het doodsoorzakenformulier is daarom op zijn plaats.

\section{Automatisch coderen is (nog) niet goed afgestemd op de klinische praktijk}

De ernst van de dementie blijkt in ons onderzoek voor de arts een belangrijke overweging om het ziektebeeld een causale rol bij overlijden toe te kennen $(\mathrm{OR}=6,6)$, hetgeen overeenstemt met heersende opvattingen onder specialisten ouderengeneeskunde [12]. De huidige software kan hiermee echter (nog) geen rekening houden. De software voor automatisch coderen ontleent zijn richtlijnen aan de ICD-10. De ernst van dementie heeft in de huidige ICD-10-classificatie van doodsoorzaken nog geen plaats. Uit ons onderzoek blijkt echter dat de factor 'ernst' zowel bij selectie als in deze classificatie zou moeten worden meegenomen om deze beter aan te laten sluiten bij de klinische praktijk.

Conform internationale richtlijnen, beschreven in deel 2 van de ICD-10, selecteert de software dementie als onderliggende doodsoorzaak wanneer dit op deel 2 van het doodsoorzakenformulier staat vermeld. ${ }^{4}$ Dit gaat vooral ten koste van long-, luchtweg- of urineweginfecties vermeld op deel 1 [13]. Uit ons onderzoek blijkt dit in meer dan de helft van de gevallen (28/54) niet overeen te stemmen met de bedoeling van de invuller. Een bijstelling van de software lijkt dan ook aangewezen om ook deze beter aan te laten sluiten bij de klinische praktijk.

\section{Sterke en zwakke punten van het onderzoek}

Vergelijkbaar onderzoek wordt (nog) niet in de literatuur aangetroffen. Vaak wordt het oordeel van de arts onderzocht aan de hand van gefingeerde casuïstiek [14]. Wij deden navraag naar de achtergrond van het feitelijk ingevulde doodsoorzakenformulier. De goede respons $(65 \%)$, het educatieve karakter (bijna $8 \%$ van de respondenten zou het doodsoorzakenformulier bij nader inzien anders hebben ingevuld) en de directe koppeling met de doodsoorzakenstatistiek zijn sterke punten van ons onderzoek te noemen. Aanvulling van onze bevindingen met kwalitatief onderzoek heeft (nog) niet plaatsgevonden en zou de interpretatie van de gegevens kunnen verrijken, vooral omdat artsen

\footnotetext{
${ }^{4}$ In 2005 geeft de WHO in een jaarlijkse update van de ICD-10 aan ziekten die de zelfzorg belemmeren, waaronder dementie, als oorzaak te beschouwen van malnutritie, anemie, cachexie of infecties. Het CBS heeft bij handmatig coderen de ICD-10-updates niet toegepast, zodat deze als integraal onderdeel van IRIS bij de invoer van het automatisch coderen in 2013 grote invloed op de statistiek hebben gehad [2].
} 
bij het invullen van het doodsoorzakenformulier begrippen anders blijken te gebruiken dan de formele definities dat voorschrijven.

De analyse van de rol van dementie als doodsoorzaak is uitsluitend en alleen gebaseerd op de volledig ingevulde vragenlijsten. Dit versterkt de bevinding van een causaal verband, maar gaat mogelijk ten koste van de representativiteit. Het percentage gevallen waarin deze 241 respondenten dementie als onderliggende doodsoorzaak selecteerden, is wat hoger dan dat van de gehele populatie respondenten $(63,9$ versus $58 \%$ ), maar wijkt hiervan niet statistisch significant af. Hetzelfde geldt voor de overeenkomstige uitkomst van het automatisch coderen $(72,2$ versus $67 \%)$. Het model dat uit ons onderzoek naar voren komt, lijkt derhalve een valide uitdrukking van de respons te zijn.

\section{Wat betekenen deze bevindingen nu voor de interpretatie van de doodsoorzakenstatistiek?}

De doodsoorzakenstatistiek is een tabellering van onderliggende doodsoorzaken, gedefinieerd als: 'de ziekte die, of het letsel dat aanleiding heeft gegeven tot de reeks van gebeurtenissen die rechtstreeks tot de dood heeft geleid' [3]. Deze ziekten vormen het aangrijpingspunt voor preventie, behandeling of beleid en worden daarom relevant geacht bij bepaling van de maatschappelijke of medische betekenis van een ziektebeeld. Landen die automatisch coderen (waaronder de Verenigde Staten, Canada, Australië en twintig EU-landen) volgen dezelfde regels bij het selecteren van een onderliggende doodsoorzaak ten behoeve van de doodsoorzakenstatistiek. Bij internationale vergelijkingen kunnen dan ook de CBScijfers worden gebruikt die voortkomen uit automatisch coderen. Hetzelfde geldt voor trends in de tijd. De uitkomsten van automatisch coderen zijn stabieler dan die van handmatig coderen doordat intra- of interobservervariaties bij het coderen goeddeels ontbreken, zodat waargenomen veranderingen met meer zekerheid aan veranderingen in ziekteverschijnselen kunnen worden toegeschreven. Gelet op het oordeel van de arts is er bij automatisch coderen echter sprake van een overschatting van dementie als onderliggende doodsoorzaak en zou het CBS-cijfer voor de Nederlandse situatie met ongeveer (minus) $23 \%$ moeten worden gecorrigeerd. Dit heeft overigens geen gevolg voor de eerste plaats die dementie in de rangorde van belangrijke doodsoorzaken inneemt. Wel is het verschil met doodsoorzaak nummer 2, longkanker, en doodsoorzaak nummer 3, de beroerte, dan veel kleiner geworden, en levert het een cijfer op dat meer recht doet aan validiteit, dat wil zeggen, een betere weergave is van de onderliggende realiteit van het overlijden aan dementie.

\section{Conclusie}

Bij automatisch coderen wordt dementie vaker als onderliggende doodsoorzaak aangemerkt dan artsen dat zouden doen. Uitgaande van het oordeel van de arts is er sprake van een mogelijke overschatting met bijna $23 \%$ in de doodsoorzakenstatistiek. Hieraan liggen foutief ingevuld doodsoorzakenformulieren, begripsverwarring en de toepassing van een in internationaal verband ontwikkeld algoritme voor selectie van dementie als onderliggende doodsoorzaak op Nederlandse doodsoorzakenformulieren ten grondslag. Aanscherping/verduidelijking van de invulinstructies en begripsverheldering zijn nodig om een correcte invulling van het doodsoorzakenformulier te bevorderen. Het inbouwen van 'ernst' als criterium in de software voor automatisch coderen kan de selectie van dementie als onderliggende doodsoorzaak verbeteren. Meer onderwijs over het vaststellen van de doodsoorzaak is nodig om het causaal denken rondom het overlijden van een patiënt te bevorderen.

\section{Literatuur}

1. Harteloh P, Hilten O van, Kardaun J. Het automatische coderen van doodsoorzaken. Een nieuwe werkwijze bij de doodsoorzakenstatistiek. Den Haag: Centraal Bureau voor deStatistiek; 2014.

2. Harteloh P. De gevolgen van automatisch coderen voor de doodsoorzakenstatistiek. Tijdschr Gezondheidswet. 2017;95:124-33.

3. WHO-FIC CC. ICD-10. Internationale statistische classificatie van ziekten en met gezondheid verband houdende problemen. Tiende Revisie. Deel 2 Handleiding voor gebruik, versie 2014. Houten: Bohn Stafleu van Loghum; 2015.

4. Iris Institute. https://www.dimdi.de/dynamic/en/ classifications/iris-institute/index.html. Geraadpleegd op: 7 aug 2018.

5. Centraal Bureau voor de Statistiek. Doodsoorzaakverklaring. https://www.cbs.nl/nl-nl/deelnemers-enquetes/ deelnemers-enquetes/decentrale-overheden/overzicht/ doodsoorzaakverklaring. Geraadpleegd op: 7 aug 2018.

6. Araújo LFS de, Dalgalarrondo P, Banzato CE. On the notion of causality in medicine: addressing Austin Bradford Hill and John L. Mackie. Arch Clin Psychiatry. 2014;41:56-61.

7. Vineis P. Causality in epidemiology. Soz Präventivmed. 2003;48:80-7.

8. Kotabagi RB, Chaturvedi RK, Banerjee A. Medical certification of cause of death. Med J Armed Forces India. 2004;60:261-72.

9. LuTH, Shau WY, Shih TP, etal. Factors associated with errors in death certificate completion. A national study in Taiwan. JClin Epidemiol. 2001;54:232-8.

10. Pritt BS, Hardin NJ, Richmond JA, et al. Death certification errors at an academic institution. Arch Pathol Lab Med. 2005;129:1476-9.

11. Maudsley G, Williams EM. 'Inaccuracy' in death certification-where are we now? J Public Health Med. 1996;18:59-66.

12. Bardelmeijer E. Gevorderde dementie is een terminale ziekte. Tijdschr Ouderengeneeskd. 2010;1:3. 
13. Harteloh PPM. Van handmatig naar automatisch coderen van doodsoorzaken: een bridge coding study. Den Haag: Centraal Bureau voor de Statistiek; 2015.

14. Dingenen ECM van, Eijk M van, Chel VGM, et al. Overleden na een val bij gevorderde dementia. Natuurlijke of niet-natuurlijke doodsoorzaak? Ned Tijdschr Geneeskd. 2018;162:D1967. 